\title{
Assessment of the Effect of Dimethyl Ether (DME) Combustion on Lettuce and Chinese Cabbage Growth in Greenhouse
}

\author{
Jayanta Kumar Basak ${ }^{1,2}$, Waqas Qasim¹, Fawad Khan', Frank Gyan Okyere', Yongjin Lee', \\ Elanchezhian Arulmozhi', Jihoon Park ${ }^{1}$, Wonjun $\mathrm{Cho}^{\mathbf{3}}$, and Hyeon Tae Kim ${ }^{1 *}$ \\ ${ }^{1}$ Department of Bio-systems Engineering, Gyeongsang National University \\ (Institute of Agriculture \& Life Science), Jinju 52828, Korea \\ ${ }^{2}$ Department of Environmental Science and Disaster Management, \\ Noakhali Science and Technology University, Noakhali-3814, Bangladesh \\ ${ }^{3}$ Bio Friends Inc. Deajeon 34028, Korea
}

\begin{abstract}
The experiment was conducted to determine the performance of DME combustion gas when used as a fuel for DME burner for raising temperature and $\mathrm{CO}_{2}$ concentration in greenhouse and also to examine its effects on chlorophyll content, and fresh and dry weight of lettuce and Chinese cabbage. DME-1 and DME-2 treatments consisted of average DME flow quantity in duct were $17.4 \mathrm{~m}^{3} \mathrm{~min}^{-1}$ and $10.2 \mathrm{~m}^{3} \mathrm{~min}^{-1}$ respectively to greenhouse-1 and greenhouse2 and no DME gas was supplied to greenhouse- 3 which was left as control (DME-3). DME supply times were $0.5 \mathrm{hr}$ day $^{-1}, 1 \mathrm{hr}$ day $^{-1}, 1: 30 \mathrm{hrs} \mathrm{day}^{-1}$ and $2 \mathrm{hrs} \mathrm{day}^{-1}$ on week 1, 2, 3, and 4 respectively. Chlorophyll content and fresh and dry weight of lettuce and Chinese cabbage were measured for each treatment and analyzed through analysis of variance with a significance level of $\mathrm{P}<0.05$. The result of the study showed that $\mathrm{CO}_{2}$ concentration increased up to $265 \%$ and $174 \%$ and the level of temperature elevated $4.8^{\circ} \mathrm{C}$ and $3.1^{\circ} \mathrm{C}$ in greenhouse- 1 and 2 , respectively as compared to greenhouse-3 due to application of DME combustion gas. Although, the same crop management practices were provided in greenhouse-1, 2 and 3 at a same rate, the highest change $(p<0.05)$ of chlorophyll content, fresh weight and dry weight were found from the DME-1 treatment, followed by DME-2. As a result, DME combustion gas that raised the level of temperature and $\mathrm{CO}_{2}$ concentration in the greenhouse-1 and greenhouse-2, might have an effect on growth of lettuce and Chinese cabbage. At end of experiment, the highest fresh and dry weight of lettuce and Chinese cabbage were measured in greenhouse-1 and followed by greenhouse-2. Similarly chlorophyll content of greenhouse-1 and greenhouse- 2 were more compared to greenhouse-3. In general, DME was not producing any harmful gas during its combustion period, therefore it can be used as an alternative to conventional fuel such as diesel and liquefied petroleum gas (LPG) for both heating and $\mathrm{CO}_{2}$ supply in winter season. Moreover, endorsed quantify of DME combustion gas for a specified crop can be applied to greenhouse to improve the plant growth and enhance yield.
\end{abstract}

Additional key words : carbon dioxide, chlorophyll, dry weight, fresh weight, temperature

\section{Introduction}

Lettuces and Chinese cabbages can be grown successfully either in spring or fall. However, there is a risk of environmental stress associated with exposing young plants to cold weather after field setting (Palada et al., 1987). It is well known that temperature and $\mathrm{CO}_{2}$ are the two conclusory factors controlling the growth of plants (Berghage, 1998; Heins et al., 2000). Lettuce and Chinese cabbage species has an optimum temperature for rapid growth rate, however lower temperatures below the optimum range

*Corresponding author: bioani@gnu.ac.kr

Received March 15, 2019; Revised August 01, 2019;

Accepted August 09, 2019 allow the plant to grow, but at a considerably reduced rate (Kalisz and Cebula, 2006). Nam et al. (1995) reported that the response of plants to unfavorable temperatures results in a modification of many physiological and biochemical processes leading to change in the chemical composition. The degree of these changes is mainly dependent on the temperature level, the temperature exposure duration and the stage of plant development. It is found that seedling stage of Chinese cabbage generally more sensitive to unfavorable thermal conditions than more developed plants (Daly and Tomkins, 1995). Low temperatures have been reported to reduce the growth of Chinese cabbage seedlings (Wiebe, 1990) and to influence their chemical composition (Moe and Guttormsen, 1985; Sasaki et al., 1996). Likewise temperature, elevated $\mathrm{CO}_{2}$ may directly or indi- 
Jayanta Kumar Basak et al.

rectly have an effect on plant production and development. It has been observed that exposure of plants to elevated $\mathrm{CO}_{2}$ resulted in a higher biomass production, an altered morphology, increased water use efficiency, increased photosynthetic activity and an enhanced carbohydrate content (Kimball, 1983; Cure, 1986; Smith et al., 1987; Lawlor and Mitchell, 1991; Woodward et al., 1991). However, the interspecific variation in response to elevated $\mathrm{CO}_{2}$ would be related to the morphology and strategy of different plant species (Poorter, 1993; Loehle, 1995). Differences in growth rate, life span and sink strength between different species have been shown to influence the effect of $\mathrm{CO}_{2}$ (Stulen et al., 1994).

Therefore, with growing concerns of controlling the factors (temperature and $\mathrm{CO}_{2}$ ) in greenhouse for crop production, DME burner using DME gas may be one alternative technique in sustainable agricultural practice. DME which is clean and considered to be economically alternative fuel is produced from natural gas through synthesis gas (Semelsberger et al., 2005). It is proved that DME and LP gas has the almost similar properties (Ogawa et al., 2003). Nowadays, DME is used widely in various fields as a fuel such as power generation, transportation, home heating and cooking, etc. (Bhattacharya et al., 2013; Olah et al., 2009; Arcoumanis et al., 2008; Kim et al., 2008; Marchionna et al., 2008). In this study, DME gas was used as a fuel for DME burner to increase temperature and $\mathrm{CO}_{2}$ concentration in greenhouse for lettuce and Chinese cabbage cultivation.

DME gas is a conversion form synthesis gas. The synthesis gas is transformed into DME through following twostep synthesis reactions (EBTP, 2011; Yuan and Eden, 2016). DME gas is also known as unpolluted fuel by burning it in agriculture facility, it is not only provide heating but also provide sufficient $\mathrm{CO}_{2}$ without any high concentration of toxic gases.

$$
\begin{aligned}
& 2 \mathrm{H}_{2}+\mathrm{CO} \leftrightarrow \mathrm{CH}_{3} \mathrm{OH}\left(\Delta \mathrm{H} 0=-90.56 \mathrm{~kJ} \mathrm{~mol}^{-1}\right) \\
& 2 \mathrm{CH}_{3} \mathrm{OH} \leftrightarrow \mathrm{CH}_{3} \mathrm{OCH}_{3}+\mathrm{H}_{2} \mathrm{O}\left(\Delta \mathrm{H} 0=-49.43 \mathrm{~kJ} \mathrm{~mol}^{-1}\right) \\
& \mathrm{CO}+\mathrm{H}_{2} \mathrm{O} \leftrightarrow \mathrm{CO}_{2}+\mathrm{H}_{2}\left(\Delta \mathrm{H} 0=-41.12 \mathrm{~kJ} \mathrm{~mol}^{-1}\right)
\end{aligned}
$$

To identify optimal amount of DME combustion gas supply to greenhouse, it is essential to quantify the complex crop-climate and phenology analysis. Many researches have been conducted to evaluate the process and application of DME for different sectors (Zhao et al., 2011; Zhang et al., 2016; Liu et al., 2013; Sun et al., 2014). However, a few number of experiments have been conducted to evaluate the impacts of DME on crop yield, especially in greenhouse where crops in winter season face low temperature stress (Basak et al., 2018; Qasim et al., 2018). Therefore, the objectives of this study were to (i) evaluate the changing pattern of temperature and $\mathrm{CO}_{2}$ concentration applying DME in a control greenhouse system and (ii) determine the impacts of DME on chlorophyll content and fresh and dry weight of lettuce and Chinese cabbage.

\section{Materials and Method}

\section{Experimental Design}

This experiment was performed in three identical greenhouses (width $3 \mathrm{~m}$, length $4 \mathrm{~m}$, height $2.5 \mathrm{~m}$ ) of Gyeongsang National University (Fig. 1). In all 3 greenhouses, there were 2 beds for planting vegetables. In one bed, lettuce was grown and, in another bed, Chinese cabbage was grown. Three tests were performed to compare and analyze the growth of lettuce and Chinese cabbage and chlorophyll content in greenhouses at different flow quantity of DME. DME supply times were $00.5 \mathrm{hr}$ day $^{-1}, 1 \mathrm{hr}$ day $^{-}$ 1, 1:30 hrs day ${ }^{-1}$ and $2 \mathrm{hrs}$ day $^{-1}$ on week $1,2,3$ and 4 respectively in every morning at 6 o'clock. The average DME flow quantity in duct was $17.4 \mathrm{~m}^{3} \mathrm{~min}^{-1}$ and 10.2 $\mathrm{m}^{3} \mathrm{~min}^{-1}$ to greenhouse- 1 and greenhouse-2 and no DME gas was supplied to greenhouse-3 which was left as control (Fig. 2). For this experiment, lettuce and Chinese cab-

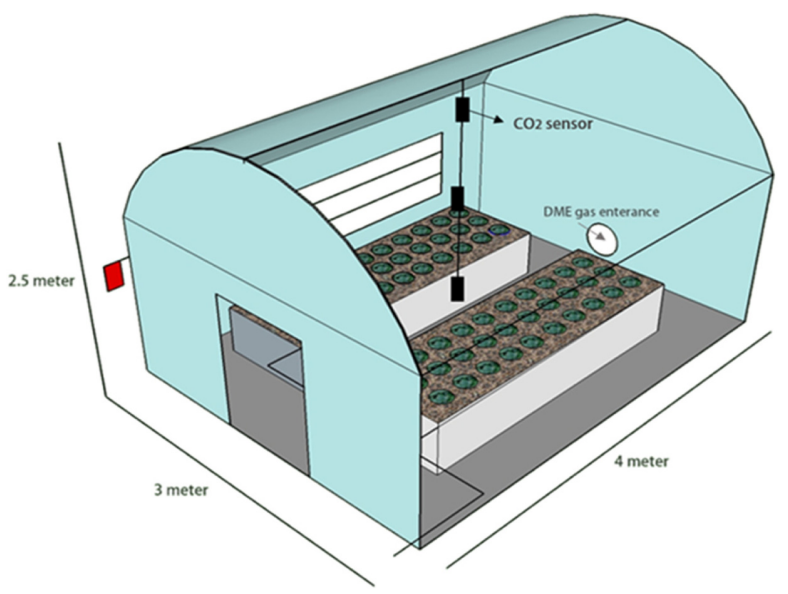

Fig. 1. Schematic diagram of Greenhouse for the experiment. 


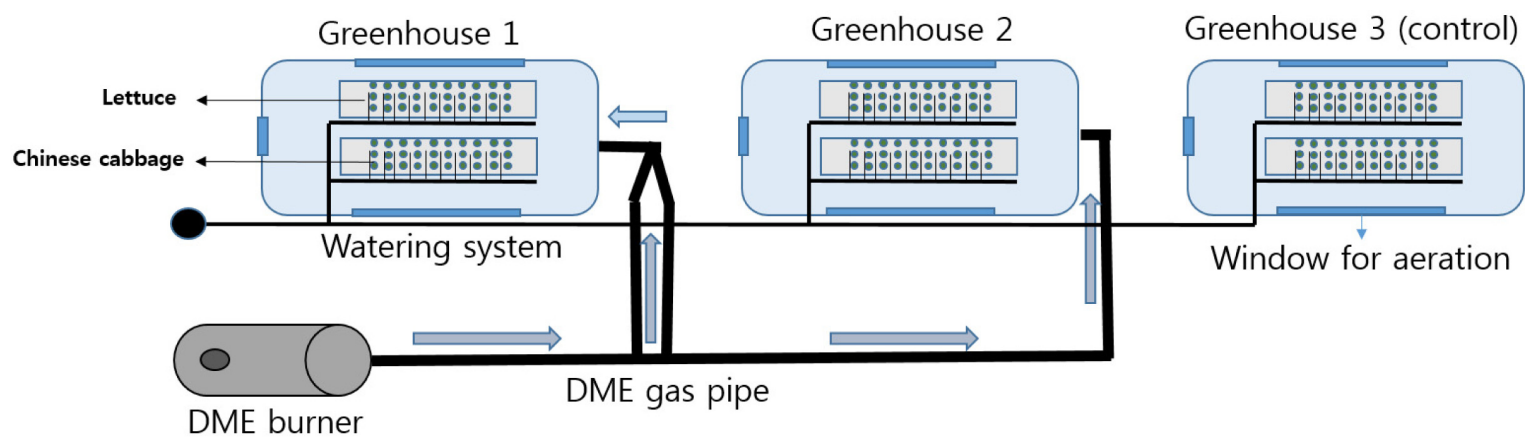

Fig. 2. Experimental design of DME supply to greenhouses.

Table 1. Physical properties of Dimethyl ether (DME)

\begin{tabular}{cc}
\hline \hline Formula & $\mathrm{CH}_{3} \mathrm{OCH}_{3}$ \\
\hline Molecular weight $\left(\mathrm{g} \mathrm{mol}^{-1}\right)$ & 46.07 \\
Density $\left(\mathrm{g} \mathrm{cm}^{-1}\right)$ & 0.661 \\
Normal boiling point $\left({ }^{\circ} \mathrm{C}\right)$ & -24.9 \\
Carbon Content $(\mathrm{wt} \%)$ & 52.2 \\
Hydrogen content $(\mathrm{wt} \%)$ & 13 \\
Oxygen content $(\mathrm{wt} \%)$ & 34.8 \\
\hline
\end{tabular}

*Density at $\mathrm{P}=1 \mathrm{~atm}$ and $\mathrm{T}=-25^{\circ} \mathrm{C}$

bage seeds were purchased from market and seeds trays were used for seedling. After 3 weeks, 30 lettuce and 30 Chinese cabbage plants were transplanted to two beds of greenhouses.

The irrigation systems were uniform in all three greenhouses. Water was provided by needles to each separate plant. The irrigation time was 2 min day ${ }^{-1}$ in all greenhouses. For aeration side windows were opened at 9:00 am and closed at 6:00 pm to keep the temperature in range.

\section{Properties of DME}

The physical properties of DME gas and the specification of DME burner are described in Table 1 and 2, respectively. For testing the concentration of gases, the samples were collected in air plastic bags (20 litter capacity) during operation of DME combustion. The sample was taken to Korean Testing laboratory on same day and ISO 6974-6 standard method was used for determination of gases concentration. The testing environment was (mean and S.D.) $19.8 \pm 5.20^{\circ} \mathrm{C}$ in temperature and $50.2 \pm 19.9 \%$ in relative humidity. Table 3 shows the concentration of gases during combustion of DME.
Table 2. The specification of the DME gas burner

\begin{tabular}{cc}
\hline \hline Items & Specification \\
\hline Quantity of energy $\left(\mathrm{kcal} \mathrm{h}^{-1}\right)$ & 40000 \\
Rotational frequency of motor $(\mathrm{rpm})$ & 1495 \\
Output of motor $(\mathrm{W})$ & 200 \\
Quantity of flow $\left(\mathrm{m}^{3} \mathrm{~min}^{-1}, \mathrm{CFM}\right)$ & 1060 \\
Diameter of outlet $(\mathrm{mm})$ & 400 \\
Length of burner $(\mathrm{mm})$ & 1360 \\
\hline
\end{tabular}

Table 3. Concentration of gases during combustion of DME

\begin{tabular}{|c|c|}
\hline Gases (unit) & Amount \\
\hline $\mathrm{CO}_{2} \mu \mathrm{mol} \mathrm{mol}{ }^{-1}(\mathrm{ppm})$ & 3316.1 \\
\hline $\mathrm{H}_{2} \mu \mathrm{mol} \mathrm{mol}{ }^{-1}(\mathrm{ppm})$ & 0.7 \\
\hline $\mathrm{CO} \mu \mathrm{mol} \mathrm{mol}{ }^{-1}$ (ppm) & 11.6 \\
\hline $\mathrm{CH}_{4} \mu \mathrm{mol} \mathrm{mol}{ }^{-1}(\mathrm{ppm})$ & 1.7 \\
\hline $\mathrm{O}_{2} \mathrm{cmol} \mathrm{mol}^{-1}(\%)$ & 21.3 \\
\hline $\mathrm{N}_{2} \mathrm{cmol} \mathrm{mol}^{-1}(\%)$ & 77.8 \\
\hline
\end{tabular}

*samples were collected in front of DME burner

\section{Data Collection and Analysis}

The plants were periodically examined after the germination stage to observe the changing pattern of plant growth and DME treatment. For measuring carbon dioxide, temperature and humidity "Lutron MCH-383SD (Lutron Electronic Enterprise Co., Ltd., Taipei, Taiwan)" electrochemical sensors were set at three different height of greenhouses. Lutron MCH-383SD is equipped to record the date, time interval and has a memory card to store these data. Data were checked at 10-min intervals and recorded data were averaged for further analysis and interpretation. The lower sensor was equipped at height of $0.3 \mathrm{~m}$ from floor which was equal with height of plants in bed. 
Jayanta Kumar Basak et al.

Fresh weight and dry weight of leaves and roots of each plant in greenhouse-1, 2 and 3 were compared at end of the experiment. Fresh weight was measured as whole plant because of high number of leaves and size of lettuce. For Chinese cabbage, 5 big leaves from each plant were taken for measuring fresh and dry weight analysis. Roots were cleaned from soil and separated from whole plants for analysis. The fresh and dry weight of plant was estimated to use digital balance (model- FX-300iWP, A\&D Company Limited, Tokyo, Japan) and drying oven (Shelves for 5EDHG6310: 2 Layers, Changsha Kaiyuan Instruments Co., Ltd, China). Number of papers were followed various temperature range and time for measuring the dry weight of plant (e.g., Arshadullah and Zaidi, 2007; Cho et al., 2007; Karimi et al., 2009). In experiment, where different treatments of plants were studied, dry weight of plant was measured to keep temperature at $80^{\circ} \mathrm{C}$ for 24 hour. Standard statistical methods were used for data evaluation including analysis variance with a significance level of $\mathrm{P}<0.05$. The significance differences between mean values of experimental data were tested with a post-hoc Tukey's HSD test. All statistical calculations were performed with Statistix10 and Statistical Package for the Social Sciences (SPSS Version: 22.0.0.0).

\section{Results and Discussion}

\section{Temperature and $\mathrm{CO}_{2}$ pattern}

Environmental factors, like temperature and $\mathrm{CO}_{2}$ are important at all stages of plant growth of lettuce and Chinese cabbage. It was examined the changing pattern of temperature and $\mathrm{CO}_{2}$ concentration due to the different levels of DME applications. The result of the study showed that the higher levels of DME application accompanied with a greater diversity $\mathrm{CO}_{2}$ concentration were confirmed the increased of temperature in this period (Fig. 3). Even the application of DME in an amount of $10.2 \mathrm{~m}^{3} \mathrm{~min}^{-1}$ was efficient to increase temperature and $\mathrm{CO}_{2}$ content in greenhouse-2. With $17.4 \mathrm{~m}^{3} \mathrm{~min}^{-1}$ and $10.2 \mathrm{~m}^{3} \mathrm{~min}^{-1}$ DME supply, the maximum $\mathrm{CO}_{2}$ were recorded $1380 \mathrm{ppm}$ and $940 \mathrm{ppm}$ in greenhouse-1 and greenhouse- 2 respectively. Average 24 hours data on temperature and $\mathrm{CO}_{2}$ during experimental period showed that $\mathrm{CO}_{2}$ concentration was increased up to $265 \%$ and $174 \%$ treated with DME at $17.4 \mathrm{~m}^{3} \mathrm{~min}^{-1}$ and $10.2 \mathrm{~m}^{3} \mathrm{~min}^{-1}$ respectively compared to control condition in every morn-
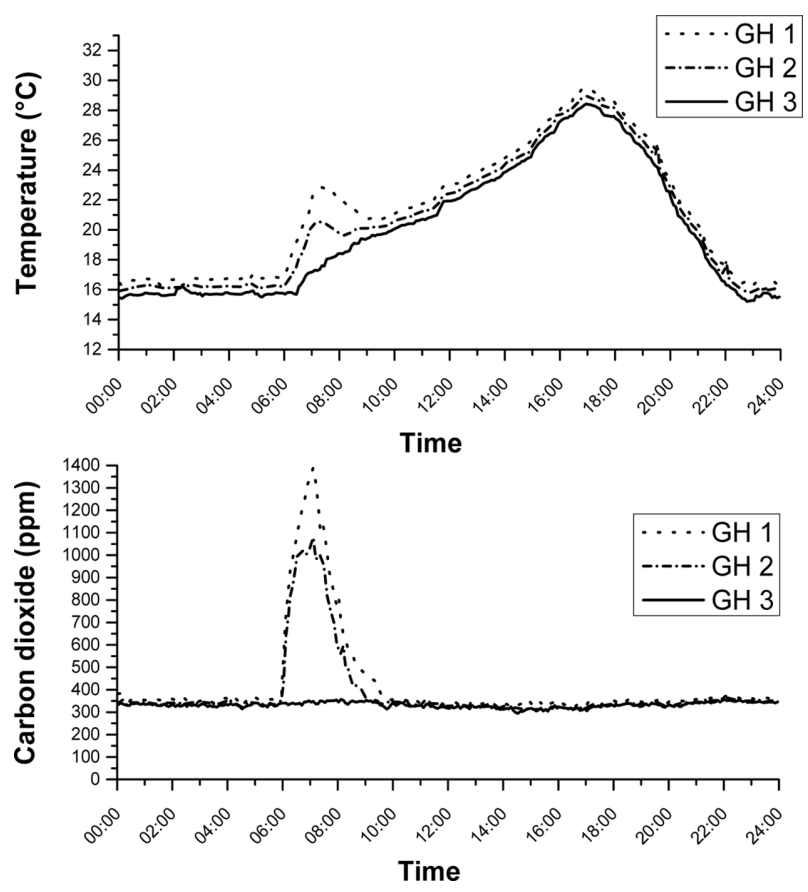

Fig. 3. Changing pattern of temperature and $\mathrm{CO}_{2}$ concentration inside the three greenhouses. The data of the figures show the mean values of the two parameters during the DME application rate was $1 \mathrm{hr}^{\text {day }}{ }^{-1}$.

ing between time intervals at 6 to 8 o'clock. Due to increase the level of $\mathrm{CO}_{2}$ in greenhouses in the same way of concentrations of DME, temperature increased up to $4.8^{\circ} \mathrm{C}$ and $3.1^{\circ} \mathrm{C}$ in greenhouse 1 and 2 respectively within this same time. On the basis of these results of changing different concentration $\mathrm{CO}_{2}$ and temperature were chosen to examine those variability chlorophyll content and fresh weight and dry weight of plant for further work. Similar results were reported by other researchers which showed that $\mathrm{CO}_{2}$ and temperature are constantly associated with the application of DME gas in greenhouse (Basak et al., 2018; Qasim et al., 2018).

\section{Fresh and Dry weight of Lettuce and Chinese cabbage}

Twenty five plants of lettuce and Chinese cabbage were collected from each greenhouse and measured the fresh and dry weight. The evaluation of the fresh and dry weight of lettuce and Chinese cabbage under different application rate of DME (DME-1, DME-2 and DME-3) in the experimental period is presented in Fig. 4 and Fig. 5. Fresh weights of lettuce were significantly different among the three treatments and time. It was maximum for DME-1 treatment compared to other two treatments. Mean $( \pm \mathrm{SD})$ 

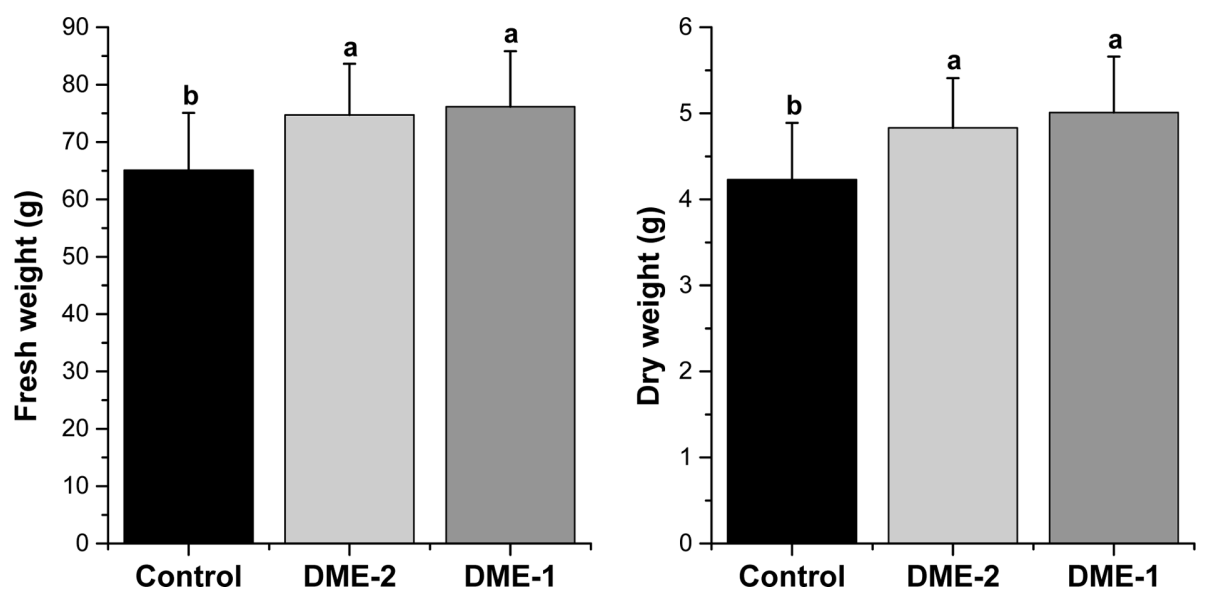

Fig. 4. Data represent means and standard deviation (SD) of fresh and dry weight of lettuce in $8^{\text {th }}$ week in three treatments in greenhouses $(n=25)$. Different letters above the bars (SD) denote significant differences of fresh and dry weight among treatments at $\mathrm{p} \leq 0.05$ based on Tukey's HSD post-hoc test.
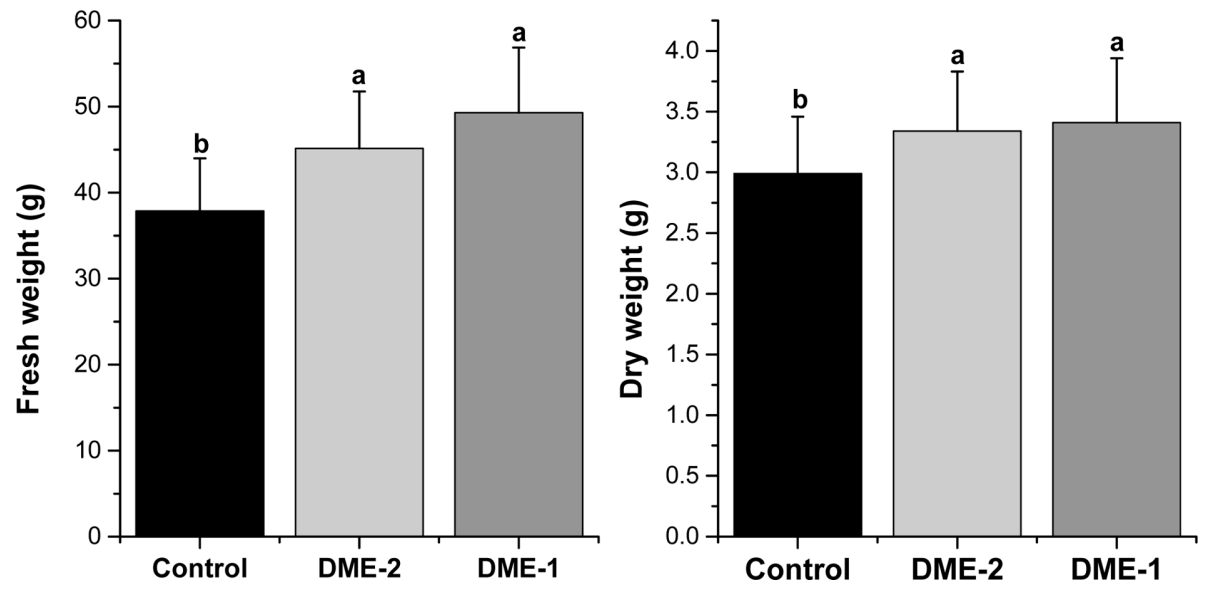

Fig. 5. Data represent means and standard deviation (SD) of fresh and dry weight of Chinese cabbage in $8^{\text {th }}$ week in three treatments in greenhouses $(\mathrm{n}=25)$. Different letters above the bars $(\mathrm{SD})$ denote significant differences of fresh and dry weight among treatments at $\mathrm{p} \leq 0.05$ based on Tukey's HSD post-hoc test.

fresh weight in gram after 8 weeks were $76.1 \pm 9.7$, $74.7 \pm 8.9$ and $65.1 \pm 9.9$ for DME-1, DME-2 and DME-3 respectively. The study found that the differences of fresh weight were significant $(\mathrm{p}<0.05)$ among DME-1, DME-2 and DME-3. In this current experiment, it was also examined that fresh weight increased up to $17.1 \%$ due to application DME at a rate of $17.4 \mathrm{~m}^{3} \mathrm{~min}^{-1}$ and $14.8 \%$ for $10.2 \mathrm{~m}^{3} \mathrm{~min}^{-1}$ compared to control treatment, thus revealing the increase in fresh weight of lettuce due to increase the amount of DME application. Moreover, due to growing time, dry weight increased at a substantial rate. It was also observed that the dry weight plant whose are directly related to fresh weight, did not keep the same rate within this experimental period. Dry weight values following declined gradually $5.01 \pm 0.65,4.8 \pm 0.58$ and $4.2 \pm 0.65$ for DME-1, DME-2 and DME-3 respectively after 8 weeks. Thus, higher dry weight was obtained for the treatments, DME-1 and DME-2 whereas the minimum dry weight of plant was observed for DME-3.

Likewise, lettuce both different rates of DME application also affect the fresh and dry weight of Chinese cabbage. Five big leaves from each plant of Chinese cabbage were taken for measuring fresh weight and dry weight analysis. When DME was applied at a rate of $17.4 \mathrm{~m}^{3} \mathrm{~min}^{-1}$ in greenhouse, fresh and dry weight of Chinese cabbage markedly increased at a range of $30.1 \%$ and $14.1 \%$ respec- 

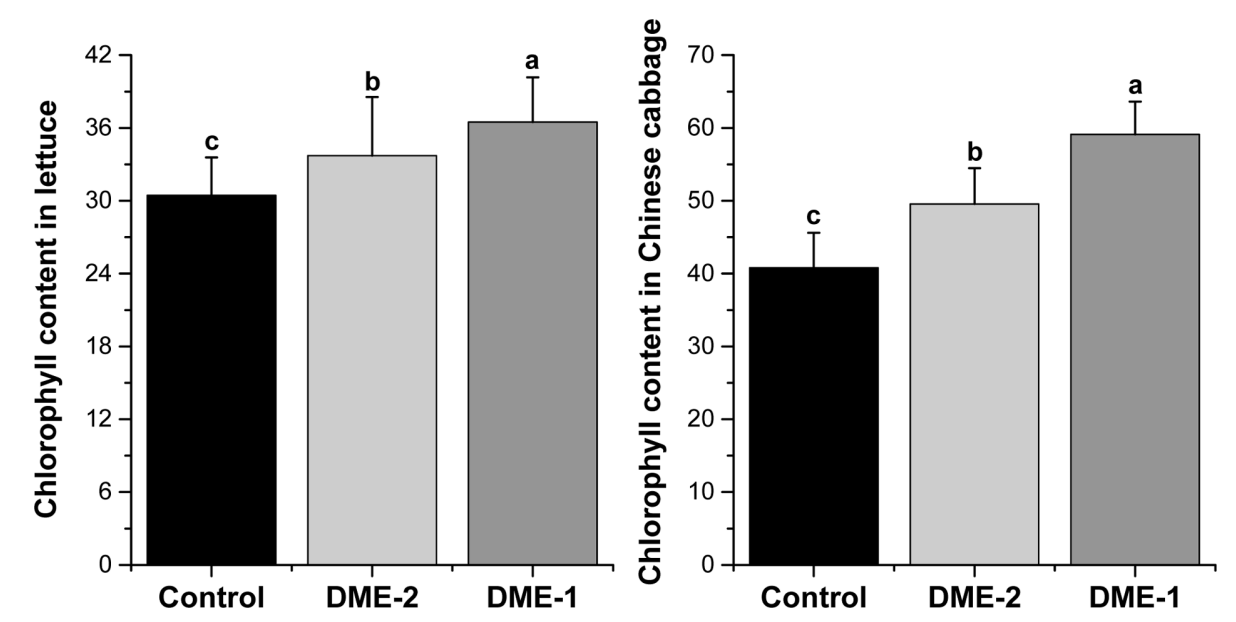

Fig. 6. Data represent means and standard deviation (SD) of chlorophyll content of lettuce and Chinese cabbage in $8^{\text {th }}$ week in three treatments in greenhouses $(n=25)$. Different letters above the bars (SD) denote significant differences of chlorophyll content among treatments at $\mathrm{p} \leq 0.05$ based on Tukey's HSD post-hoc test.

tively relative to the control treatment. In response to DME at a rate of $10.2 \mathrm{~m}^{3} \mathrm{~min}^{-1}$, fresh and dry weight increased up to $19.3 \%$ and $11.7 \%$ respectively. DME- 1 and DME-2 treatments which caused rise in temperature and $\mathrm{CO}_{2}$ in greenhouse was found to have an effect on the fresh and dry matter of lettuce and Chinese cabbage seedlings. Temperature of 18 to $22^{\circ} \mathrm{C}$ was optimum for Chinese cabbage heading and 10 to $13^{\circ} \mathrm{C}$ for the final head development, with growth reduction occurring when temperature is below $10^{\circ} \mathrm{C}$ (Burt et al., 2006). According to Moe and Guttormsen (1985), the increase of temperature in the growing stage resulted in higher dry matter of Chinese cabbage seedlings. A marked increase of fresh matter in Chinese cabbage grown at higher temperatures also observed by Noto and Leonardi (1995). On the other hand, the reduction in growth of cabbage seedlings held in low temperature was observed by Sasaki et al. (1996). Wiebe (1990) mentioned that the number of leaves in Chinese cabbage seedlings raised clearly with higher temperature compared with those subjected to low temperature. Likewise, temperature elevated $\mathrm{CO}_{2}$ may directly, or indirectly, effect on plant production and development. It has been noted that exposure of plants to elevated $\mathrm{CO}_{2}$ resulted in a higher biomass production and an enhanced carbohydrate content (Lawlor and Mitchell, 1991; Woodward et al., 1991). Similar effect was described by Gray (2015) for lettuce plant. The results obtained in this study indicated that DME application during growing stage were more beneficial for plant growth.

\section{Chlorophyll content in Lettuce and Chinese cabbage}

The chlorophyll content results are presented as an average of the measurement in all 3 greenhouses (Fig. 6). DME application levels had a significant $(\mathrm{p}<0.05)$ effect chlorophyll content in lettuce and Chinese cabbage. The mean values of chlorophyll content in lettuce were recorded $36.48 \pm 3.7,33.7 \pm 4.8$ and $30.4 \pm 3.1$ for DME-1, DME-2 and DME-3 respectively at the end of $8^{\text {th }}$ week. However, the mean values of chlorophyll content in Chinese cabbage were obtained 59.1 $\pm 4.5,49.5 \pm 4.9$ in DME-1 and DME-2 respectively where it was $40.8 \pm 4.8$ for DME-3. Thus, chlorophyll content was obtained high for the treatments DME1 and DME-2 whereas the minimum chlorophyll content was observed for DME-3. So from these results it is suggested that DME supply to greenhouse occurred high $\mathrm{CO}_{2}$ can be effective for chlorophyll content of leaves. $\mathrm{CO}_{2}$ being the substrate of photosynthesis, the increase in $\mathrm{CO}_{2}$ concentration increases the net photosynthetic rate and crop productivity (Kimball, 1983; Ziska et al. 1997). In reviewing a number of studies of the effects of $\mathrm{CO}_{2}$ on enrichment of leaf chlorophyll content (Evans, 1989; Gifford, 1992; Houpis et al., 1988; Idso and Kimball, 1992; Idso et al., 1991; Idos et al., 1993). Pinter et al. (1994) observed slightly higher per-unit-leaf-area chlorophyll contents in plants exposed to elevated $\mathrm{CO}_{2}$. In another experiment with alfalfa, for example, plants grown at an atmospheric $\mathrm{CO}_{2}$ concentration of $600 \mathrm{ppm}$ actually displayed greater leaf chlorophyll concentrations than those observed in plants grown at 340 ppm (Sgherri et al., 1998). 


\section{Conclusions}

The current study demonstrates the effects of DME combustion gas on fresh weight, dry weight and chlorophyll content in lettuce and Chinese cabbage, which are important factors for higher yields. Higher concentration of $\mathrm{CO}_{2}$ generated by DME combustion gas in greenhouse showed higher efficiency on fresh weight, dry weight and chlorophyll content of plant. The result of the study showed that, fresh and dry weights of lettuce and Chinese cabbage in greenhouse-1 obtained from DME-1 $\left(17.4 \mathrm{~m}^{3} \mathrm{~min}^{-1}\right)$ treatment were higher compared to other two treatments (DME2 and DME-3). Moreover, the contents of chlorophyll were better in greenhouse- 1 and 2 as compared to control greenhouse. To improve the yield, in response to the above mentioned three parameters, DME gas usage is important in developing new decision making by farmers and researchers for its application under extreme cold condition in greenhouse. Moreover, this study creates a scope for further research using DME combustion gas in greenhouses to measure growth performance of different crops. In addition, it is essential to quantify the accurate rate of DME combustion gas for a specified crop, which can be helpful to improve the plant growth and enhance yield.

\section{Acknowledgements}

This work was supported by Korea Institute of Planning and Evaluation for Technology in Food, Agriculture and Forestry (IPET) through Agriculture, Food and Rural Affairs Research Center Support Program, funded by Ministry of Agriculture, Food and Rural Affairs (MAFRA) (Grant number: 116113-02).

\section{Literature Cited}

Arcoumanis, C., C. Bae, R. Crookes, and E. Kinoshita. 2008. The potential of di-methyl ether (DME) as an alternative fuel for compression-ignition engines: A review. Fuel 87:1014-1030.

Basak, J.K., W. Qasim, F. Khan, F.G. Okyere, J. Park, E. Arulmozhi, Y.J. Lee, and H.T. Kim. 2018. Assessment of changing pattern of temperature and $\mathrm{CO}_{2}$ by using DME combustion gas for enhanced growth of pepper plant in greenhouse. Korean Society for Agricultural Machinery and ARCs 2018 Autumn Conference, 18-19 October, 2018, Seoul National University, Seoul, Korea.
Berghage, R. 1998. Controlling height with temperature. HortTechnology 8:535-539.

Bhattacharya, S., K.B. Kabir, and K. Hein. 2013. Dimethyl ether synthesis from Victorian brown coal through gasification current status, and research and development needs. Progress in Energy and Combustion Science 39:577-605.

Burt, J., D. Phillips, and D. Gatter. 2006. Growing Chinese cabbage in Western Australia. Department of Agriculture and Food, Western Australia, Perth. Bulletin 4673.

Cure, J.D. 1986. Crop responses to carbon dioxide doubling: A literature survey. Agricultural and Forest Meteorology 38:127-145.

Daly, P., and B. Tomkins. 1995. Production and postharvest handling of Chinese cabbage (Brassica rapa var. pekinensis). The Rural Industries Research and Development Corporation (RIRDC) 97(1):41.

EBTP (European Biofuels Technology Platform). 2011. Dimethyl ether (DME). European Biofuels technology platform. Available at: http://www.etipbioenergy.eu/images/AllBiofuelFactsheets2016.pdf

Evans, J.R. 1989. Photosynthesis and nitrogen relationships in leaves of $\mathrm{C}_{3}$ plants. Oecologia 78:9-19.

Gifford, R.M. 1992. Interaction of carbon dioxide with growth-limiting environmental factors in vegetation productivity: Implications for the global carbon cycle. Adu. Bioclim 1:24-58.

Gray, D. 2015. Effects of temperature on the germination and emergence of lettuce (Lactuca Sativa, L.) varieties. Journal of Horticultural Science 50:349-361.

Heins, R.D., B. Liu, and E.S. Runkle. 2000. Regulation of crop growth and development based on environmental factors. Acta Horticulture 511:15-26.

Houpis, J.L.J., K.A. Surano, S. Cowles, and J.H. Shinn. 1988. Chlorophyll and carotenoid concentrations in two varieties of Pinus ponderosa seedlings subjected to long-term elevated carbon dioxide. Tree Physiology 4:187-193.

Idso, S.B., B.A. Kimball, and D.L. Hendrix. 1993. Air temperature modifies the size-enhancing effects of atmospheric $\mathrm{CO}_{2}$, enrichment on sour orange tree leaves. Environmental and Experimental Botany 33:293-299.

Idso, S.B., and B.A. Kimball. 1992. Aboveground inventory of sour orange trees exposed to different atmospheric $\mathrm{CO}_{2}$ concentrations for 3 full years. Agricultural and Forest Meteorology 60:145-151.

Idso, S.B., B.A. Kimball, and S.G. Allen. 1991. $\mathrm{CO}_{2}$ enrichment of sour orange trees: 2.5 years into a long-term experiment. Plant Cell Environment 14:351-353.

Kalisz, A., and S. Cebula. 2006. The effect of temperature on growth and chemical composition of Chinese cabbage seedlings in spring period. Folia Horticulture 18:3-15.

Kim, M.Y., S.H. Yoon, B.W. Ryu, and C.S. Lee. 2008. Combustion and emission characteristics of DME as an alternative fuel for compression ignition engines with a high 
Jayanta Kumar Basak et al.

pressure injection system. Fuel 87:2779-2786.

Kimball, B.A. 1983. Carbon dioxide and agricultural yield: an assemblage and analysis of 430 prior observations. Agronomy Journal 75:779-788.

Lawlor, D.W., and A.C. Mitchell. 1991. The effects of increasing $\mathrm{CO}_{2}$ on crop photosynthesis and productivity: A review of field studies. Plant, Cell and Environment 14:807-818.

Liu, G.B., Q.D. Zhang, Y.Z. Han, N. Tsubaki, and Y.S. Tan. 2013. Selective oxidation of dimethyl ether to methyl formate over trifunctional $\mathrm{MoO}_{3}-\mathrm{SnO}_{2}$ catalyst under mild conditions. Green Chemistry 15:1501-1504.

Marchionna, M., R. Patrini, D. Sanfilippo, and G. Migliavacca. 2008. Fundamental investigations on di-methyl ether (DME) as LPG substitute or make-up for domestic uses. Fuel Processing Technology 89:1255-1261.

Moe, R., and G. Guttormsen. 1985. Effect of photoperiod and temperature on bolting in Chinese cabbage. Scientia Horticulture 27:49-54.

Nam, J.H., W.H. Kang, and I.S. Kim. 2001. Effect of cold acclimation and deacclimation on the freezing tolerance, total RNA, soluble protein and soluble sugar in Chinese cabbage. Journal of Bio-Environmental Control 10:244-250.

Noto, G., and C. Leonardi. 1995. Response of Chinese cabbage [Brassica rapa L.ssp pekinensis (Lour.) Olsson] to thermal conditions. Italus Horticultural 2:37-42.

Ogawa, T., N. Inoue, T. Shikada, and Y. Ohno. 2003. Direct dimethyl ether synthesis. Journal of Natural Gas Chemistry 12:219-227.

Olah, G.A., A. Goeppert, and G.K.S. Prakas. 2009. Chemical recycling of carbon dioxide to methanol and dimethyl ether: From greenhouse gas to renewable, environmentally carbon neutral fuels and synthetic hydrocarbons. The Journal of Organic Chemistry 74:487-498.

Palada, M.C., S. Ganser, and R.R. Harwood. 1987. Cultivar evaluation for early and extended production of Chinese cabbage in eastern Pennsylvania. Horticulture Science 22:1260-1262.

Pinter, P.J., S.B. Idso, D.L. Hendrix, R.R. Rokey, R.S. Rauschkolb, J.R. Mauney, B.A. Kimball, G.R. Hendrey, K.F. Lewin, and J. Nagy. 1994. Effect of free-air $\mathrm{CO}_{2}$ enrichment on the chlorophyll content of cotton leaves. Agricultural and Forest Meteorology 70:163-169.

Poorter, H. 1993. Interspecific variation in the growth response of plants to an elevated ambient $\mathrm{CO}_{2}$ concentration. Vegetatio 104/105:77-97.

Qasim, W., J.K. Basak, F.G. Okyere. F. Khan, Y.J. Lee, and H.T. Kim. 2018. Effect of Dimethyl ether (DME) Combustion on Lettuce and Chinese cabbage Growth in Greenhouse. AGENG CONFERENCE 2018, New engineering concepts for a valued agriculture, 8-12 July 2018, Wageningen, the Netherlands.

Sasaki, H., K. Ichimura, and M. Oda. 1996. Changes in sugar content during cold acclimation and deacclimation of cabbage seedlings. Annals of Botany 78:365-369.

Semelsberger, T.A., R.L. Borup, and H.L. Greene. 2006. Dimethyl ether (DME) as an alternative fuel. Journal of Power Sources 156:497-511.

Sgherri, C.L.M., M.F. Quartacci, M. Menconi, A. Raschi, and F. Navari-Izzo. 1998. Interactions between drought and elevated $\mathrm{CO}_{2}$ on alfalfa plants. Journal of Plant Physiology 152:118-124.

Smith, S.D., B.R. Strain, and T. Sharkey. 1987. Effects of $\mathrm{CO}_{2}$ enrichment on four great basin grasses. Functional Ecology 1:139-143.

Stulen, I., J. Den Hertog, F. Drelon, and J. Roy. 1994. An integrated approach to the influence of $\mathrm{CO}_{2}$ on plant growth using data for three herbaceous species. - In: Roy J. and E. Garnier (Eds.), A whole plant perspective on carbon nitrogen interactions, pp. 229-245, SPB Academic Publishing.

Sun, J., G. Yang, Y. Yoneyama, and N. Tsubaki. 2014. Catalysis chemistry of dimethyl ether synthesis. ACS Catalysis 4:3346-3356.

Wiebe, H.J. 1990. Estimation of the raising temperature at time of bolting of Chinese cabbage. Acta Horticulture 267:297-303.

Woodward, F.L., G.B. Thompson, and I.F. Mckee. 1991. The effects of elevated concentrations of carbon dioxide on individual plants, populations, communities and ecosystems. Annals of Botany 67:23-38.

Yuan, Z., and M.R. Eden. 2016. Toward the development and deployment of large-scale carbon dioxide capture and conversion processes. Industrial and Engineering Chemistry Research 55:3383-3419.

Zhang, Z.Z., Q.D. Zhang, L.Y. Jia, W.F. Wang, T. Zhang, Y.Z. Han, N. Tsubaki, and Y.S. Tan. 2016. Effects of tetrahedral molybdenum oxide species and $\mathrm{MoO}_{\mathrm{x}}$ domains on the selective oxidation of dimethyl ether under mild conditions. Catalysis Science \& Technology 9:2975-2984.

Zhao, Q., H. Wang, Z.F. Qin, Z.W. Wu, J.B. Wu, W.B. Fan, and J.G. Wang. 2011. Synthesis of polyoxymethylene dimethyl ethers from methanol and trioxymethylene with molecular sieves as catalysts. Journal of Fuel Chemistry and Technology 39:918-923.

Ziska, L.H., O. Namuo, T. Moya, J. Quilang. 1997. Growth and yield response of field grown tropical rice to increasing carbon dioxide and air temperature. Agronomy Journal 89:45-53. 


\title{
온실에서 상추와 배추를 이용한 DME 원료 난방 효율분석
}

\author{
쟌타 구마 바삭 ${ }^{1,2}$. 와카스 카심 ${ }^{1}$ - 파와드 칸 ${ }^{1}$. 프랑크 갼 오시레 ${ }^{1} \cdot$ 이용진 $^{1}$, \\ 에린지 아루모지 ${ }^{1} \cdot$ 박지훈 $^{1} \cdot$ 조원준 $^{3}$ - 김현테 ${ }^{1 *}$ \\ 1경상대학교(농업생명과학원), 생물산업기계공학과 \\ 2노아칼리 과학기술대학 환경공학과, ${ }^{3}$ 바이오프렌즈(주)
}

\begin{abstract}
적 요. 본 연구는 온실의 온도와 $\mathrm{CO}_{2}$ 농도를 높이기 위해 $\mathrm{DME}$ 버너용 연료로 $\mathrm{DME}$ 가스를 사용했을 때 $\mathrm{DME}$ 연소가스의 성능을 결정하고 겨울에 상추와 양배추의 엽록소 함량 그리고 무게와 건조무게에 대한 영향정도를 조사하기 위해 수행되었다. 각각 온실1과 온실2에 처방 된 DME-1과 DME-2 처방은 덕트의 평균 DME 유량 $17.4 \mathrm{~m}^{3} \mathrm{~min}^{-1}$ 과 $10.2 \mathrm{~m}^{3} \mathrm{~min}^{-1}$ 으로 구성됐으며, 대조군(DME-3)으로 남겨진 온실3에는 $\mathrm{DME}$ 가스가 공급되지 않 았다. DME 공급 시간은 각각 주차 별로 1 주차는 하루당 0.5 시간, 2 주차는 1 시간, 3 주차는 1.5 시간, 4 주차는 2 시간으로 설정하였다. 각각 처방마다 엽록소 함량과 상추와 배추의 건조 전, 후 중량을 측정했으며, 연구결과 무처리구인 온실 3 과 비교하여 온실1과 온실2 의 $\mathrm{CO}_{2}$ 농도는 각각 $265 \%, 174 \%$ 증가하였고, 온도의 경우 $4.8^{\circ} \mathrm{C}, 3.10^{\circ} \mathrm{C}$ 상승하였다. $\mathrm{DME}$ 가스를 제외한 다른 조건이 같은 온실에서 재배된 상추와 양배추의 엽록소 함량과 생체중, 건물중은 온실1에서 (유의적으로) 가장 높았으며, 온실2는 대조구 온실보다 높았다. 이러한 결 과는 $\mathrm{DME}$ 가스 연소에 의한 $\mathrm{CO}_{2}$ 농도 차이에 기인된 것으로 판단된다. 일반적으로 가스연소에 의해 발생되는 유해가스 증상은 나타나지 않았으며 동절기 난방과 $\mathrm{CO}_{2}$ 공급이 동시에 필요할 경우 $\mathrm{DME}$ 가스가 기존의 경유 또는 LPG 등을 대체할 수 있는 가능성을 확인하였다. 향후 정밀한 연구를 통하여 효율적인 난방방식으로의 검토가 적극 필요하다고 판단된다.
\end{abstract}

추가 주제어: 이산화탄소, 엽록소, 건물중, 생체중, 온도 